\title{
Leptin in the canine uterus and placenta: possible implications in pregnancy
}

\author{
Orsolya Balogh ${ }^{1 *}$, Livia P Staub', Aykut Gram², Alois Boos², Mariusz P Kowalewski ${ }^{2+}$ and Iris M Reichler ${ }^{1+}$
}

\begin{abstract}
Background: Leptin (Lep) is known for its involvement in the regulation of reproductive functions. It is important for uterine receptivity, implantation, placental growth and maternal energy homeostasis in several species, but Lep's function in the pregnant dog has not been investigated.

Methods: Pregnant bitches were ovariohysterectomized at pre-implantation, post-implantation, mid-gestation and prepartum luteolysis. Two additional groups were treated with aglepristone in mid-gestation, and ovariohysterectomized 24 or $72 \mathrm{~h}$ later. Lep and leptin receptor (LepR) gene expression was detected by semi-quantitative real-time PCR in pre-implantation and inter-placental uterine sections (Ut) and in utero-placental compartments (Ut/PI). Immunohistochemistry and in situ hybridization (ISH) were performed for Lep and LepR protein and mRNA localization. Parametric one-way ANOVA, paired $t$-test and Wilcoxon signed-rank test were used for statistical analysis.
\end{abstract}

Results: In the Ut/PI, Lep expression was higher at post-implantation and prepartum luteolysis than at mid-gestation, while in the Ut, Lep mRNA levels did not change during pregnancy. LepR expression in the Ut/PI was up-regulated at prepartum luteolysis compared to the earlier stages. In the Ut, highest LepR mRNA was found at pre- and post-implantation. LepR expression was down-regulated in the Ut/PI compared to the Ut at post-implantation and at mid-gestation. Aglepristone treatment resulted in a decrease of Lep mRNA levels from 24 to $72 \mathrm{~h}$ in the Ut without concomitant changes in the Ut/PI or in LepR levels. Lep and LepR immunoreactivities were strong in the luminal and glandular epithelium in the Ut with abundant LepR signals in the subepithelial stroma. In the Ut/PI, fetal trophoblasts stained stronger for Lep and LepR than decidual cells, and signals for both proteins were also detected in the glandular chambers. The myometrium, blood vessel media, and sporadically also the endothelium stained for Lep and LepR. ISH showed similar signal distribution in the Ut and Ut/PI.

Conclusions: Lep and LepR are differentially expressed in the canine uterus and placenta during pregnancy, and their presence in various cell types indicates paracrine/autocrine roles. The Lep signaling system may be one of the pathways involved in feto-maternal cross-talk, implantation and maintenance of pregnancy, and may have a regulatory role around parturition.

Keywords: Leptin, Leptin receptor, Dog, Gestation, Uterus, Placenta, Immunohistochemistry, In situ hybridization

\section{Background}

Leptin (Lep) was originally thought to be secreted exclusively by adipose tissue, regulating energy metabolism and satiety [1]. Soon thereafter it became clear that Lep affects reproductive processes both centrally and peripherally, and its local expression within reproductive tissues also supports paracrine/autocrine actions through its receptors

\footnotetext{
* Correspondence: obalogh@vetclinics.uzh.ch

${ }^{\dagger}$ Equal contributors

${ }^{1}$ Clinic of Reproductive Medicine, Vetsuisse-Faculty, University of Zurich,

Winterthurerstrasse 260, 8057 Zurich, Switzerland

Full list of author information is available at the end of the article
}

[2-7]. During gestation, Lep concentrations in maternal serum are significantly increased in, e.g., women, rats, mice and mares [8-12] and decrease after birth, indicating a physiological role in pregnancy. Besides adipose tissue, human, rat and murine placentae also express Lep $[10,13,14]$, but it seems that the placental contribution to circulating levels is only functionally significant in women [7]. Lep regulates various processes that are crucial for placental development and function including nutrient transfer across and within the placenta $[15,16]$. Additionally, Lep has also angiogenic properties $[17,18]$.

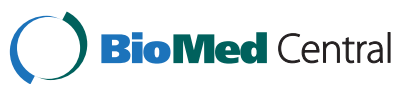

(C) 2015 Balogh et al.; licensee BioMed Central. This is an Open Access article distributed under the terms of the Creative Commons Attribution License (http://creativecommons.org/licenses/by/4.0), which permits unrestricted use, distribution, and reproduction in any medium, provided the original work is properly credited. The Creative Commons Public Domain Dedication waiver (http://creativecommons.org/publicdomain/zero/1.0/) applies to the data made available in this article, unless otherwise stated. 
Fetal trophoblast cells invade the maternal endometrium in species with invasive placentation like humans, rodents, and to some extent also in dogs [19]. Lep promotes trophoblast invasion in humans by acting on matrix metalloproteinase 2 (MMP-2) and MMP-9, which are regarded as key enzymes for successful implantation $[20,21]$. In vitro, Lep stimulated MMP-2 secretion and the activity of MMP-2 and MMP-9 from human cytotrophoblasts [22,23] as well as invasion by day 10 murine trophoblast cells [24]. Furthermore, already in early pregnancy, both at the pre-implantation phase and during the window of implantation, Lep was shown to regulate uterine receptivity and embryo development in species other than the dog [25-30]. Human endometrial epithelial cells treated with Lep in vitro expressed higher levels of $\beta 3$ integrin, leukemia inhibitory factor (LIF), interleukin-1 (IL-1) and their receptors [25,26], which facilitate embryo adhesion and have immuno-modulatory roles during embryo-maternal interaction. It seems that the developing pre-implantation embryo is under the local influence of maternal Lep in the uterus and can respond to it, as LepR expression was found in oocytes and embryos from the 2-cell to 8-cell or blastocyst stages [27-29]. Lep increased cell numbers and blastocyst formation rates in murine and ovine embryos [27,28], but reduced quality and developmental rate in horses [29].

In dogs, maintenance of pregnancy is dependent on an adequate supply of progesterone (P4), the sole source of which is the corpus luteum (CL), as the placenta is devoid of steroidogenic activity [31-33]. The luteal phase in pregnant and non-pregnant dogs is comparable in length and in peripheral levels of P4, estrogens and prolactin (PRL), and only relaxin concentrations are different since it is produced by the placenta [32,34-36]. Therefore, other endocrine and molecular mechanisms may already be crucial early on to support survival of the embryo and to maintain a successful pregnancy. During early canine embryo-maternal contact, differential gene expression of members of the prostaglandin synthesis pathway, growth factors, cytokines, immune cell receptors, steroid hormone receptors and the PRL receptor points to the role of the blastocyst to interact with the uterine milieu to signal its presence [37-40]. Some of the above-mentioned factors are also expressed at the time of implantation-placentation, as shown by Beceriklisoy et al. [39], Kowalewski et al. $[41,42]$ and Gram et al. [43].

Lep's role in canine reproduction and especially during pregnancy is not extensively studied and is poorly understood, although the positive relationship with short- and long-term energy status and obesity is well known [44-46]. Lep is produced in proportion to the amount of fat depots, and its peripheral concentration correlates with adiposity regardless of gender, breed, age and neuter status [46]. However, Saleri et al. [47] measured higher levels of
Lep in female than in male dogs, which also varied according to the stage of the reproductive cycle. Up-regulation of Lep gene expression in the CL during the early luteal phase in non-pregnant bitches [48], and the presence of Lep immunoreactive protein in luteal cells and in granulosa cells of mature luteinized follicles [49], may indicate a positive action of Lep on follicular and luteal function and perhaps on steroid hormone production in the dog. To date, Lep expression in the canine uterus was only examined in the first half of gestation using qualitative PCR, which yielded negative results [37,39]. Bartel et al. [50] found Lep and LepR immunoreactivity in the uteri of non-pregnant bitches, but pregnant dogs were not studied.

The role of Lep in canine uterine and placental function during gestation is still not clear and has not been investigated in detail. We hypothesize that the canine placenta is a source of Lep, and that Lep signaling may be involved in the regulation of pregnancy establishment and maintenance. Therefore, in this study, we determined relative gene expression of Lep and LepR in fullthickness uterine (Ut) and utero-placental (Ut/Pl) sections of bitches from various stages of pregnancy and after aglepristone-induced abortion in mid-gestation; the latter experiment was to compare to changes occurring during parturition. Additionally, Lep and LepR protein and mRNA were localized by immunohistochemistry (IHC) and in situ hybridization (ISH), respectively, in representative sections of the Ut and Ut/Pl during gestation.

\section{Methods}

All uterine and utero/placental tissues used in this study were collected in the framework of previous studies [41,51], in accordance with the appropriate animal welfare legislations. Animal experiments were approved by the respective ethics committees and conducted under permit no. II 25.319c20-15c GI 18/14 and VIG3-19c20/15c GI 18,14 (JustusLiebig University, Giessen), and permit no. Ankara 2006/ 06 (Faculty of Veterinary Medicine, University of Ankara).

\section{Animals}

Healthy bitches (2-8 years, different breeds) were mated 2 days after ovulation (serum $\mathrm{P} 4 \geq 5 \mathrm{ng} / \mathrm{mL}$ ) [52]. Day of mating was designated as day 0 . Dogs were ovariohysterectomized on d 8-12 (pre-implantation, $\mathrm{n}=5$ ), $\mathrm{d} 18-25$ (post-implantation; $\mathrm{n}=5$ ), d 35-40 (mid-gestation; $\mathrm{n}=5$ ) and during prepartum luteolysis $(\mathrm{n}=3$; defined as $\mathrm{P} 4<$ $3 \mathrm{ng} / \mathrm{ml}$ in two consecutive serum samples taken $6 \mathrm{~h}$ apart starting from d 58). Additionally, bitches on d 40-45 of gestation were treated with the progesterone-receptor blocker aglepristone (Alizin ${ }^{\circledR}$, Virbac, Carros Cedex, France; $10 \mathrm{mg} / \mathrm{kg}$ BW subcutaneously twice, $24 \mathrm{~h}$ apart) to induce abortion, and were ovariohysterectomized 24 or $72 \mathrm{~h}$ after the last injection ( $\mathrm{n}=4$ per group). At the pre-implantation 
stage, pregnancy was confirmed by detecting embryos in uterine flushes immediately after surgery.

\section{Tissue samples}

Full thickness Ut samples were collected from bitches in the pre-implantation group. From the post-implantation stage until prepartum luteolysis, full thickness $\mathrm{Ut} / \mathrm{Pl}$ and inter-placental Ut sections were collected. Inter-placental Ut was not available from the prepartum luteolysis group. For preservation of RNA, all tissues were incubated overnight in RNAlater ${ }^{\circledR}$ at $4^{\circ} \mathrm{C}$ (Ambion Biotechnologie $\mathrm{GmbH}$, Wiesbaden) and afterwards stored at $-80^{\circ} \mathrm{C}$. For $\mathrm{IHC}$ and ISH, all tissues were fixed in $10 \%$ neutral phosphatebuffered formalin at $4^{\circ} \mathrm{C}$ for $24 \mathrm{~h}$, washed daily in phosphate buffered saline for one week, dehydrated in a graded ethanol series and embedded in paraffin-equivalent HistoComp (Vogel, Giessen, Germany) or paraffin [41,53].

\section{Semi-quantitative real-time (TaqMan) PCR}

After isolation of total RNA using TRIzol ${ }^{\circledR}$ Reagent (Invitrogen, Carlsbad, CA, USA), 100-200 ng of RNA per sample was DNAse treated (RQ1 RNase-free DNase; Promega, Dübendorf, Switzerland) to eliminate genomic DNA contamination according to the manufacturer's instructions and as previously described [54]. Reverse transcription was carried out in an Eppendorf Mastercycler Thermal Cycler (Vaudaux-Eppendorf AG, Basel, Switzerland) using reagents from Applied Biosystems (Foster City, CA, USA) according to our protocols [54]. Semi-quantitative real-time (TaqMan) PCR for the detection of canine Lep [GenBank: NM_001003070] and LepR [GenBank: NM_001024634; only the long isoform is known] was carried out using the same primers and TaqMan probes as previously reported by our group [48], i.e.,: Lep (forward): 5-GGG TCG CTG GTC TGG ACT T-3', Lep (reverse): 5'-CTG TTG GTA GAT GGC CAA CGT-3', Lep TaqMan probe: 5'-TCC TGG GCT CCA ACC AGT CCT GAG T-3'; LepR (forward): 5'-CAT TTG CGG AGG GAT GGT T-3', LepR (reverse): 5'-AGC GGT TTC ACC ACG GAA T-3', LepR TaqMan probe: 5'-TTG ACT CTT CAC CAA CGT GTG TGG TTC C-3'. TaqMan probes were labeled at the 5 -end with the reporter dye 6-carboxyfluorescein (FAM), and at the 3'-end with the quencher 6-carboxytetramethylrhodamine (TAMRA). Reactions were carried out in an automated fluorometer (ABI PRISM $\mathrm{TM}_{\mathrm{TM}} 7500$ Sequence Detection System, Applied Biosystems, Darmstadt, Germany) using 96-well optical plates following our protocols $[55,56]$. Samples were run in duplicates. Canine GAPDH [GenBank: AB028142] (GAPDH (forward): 5'GCT GCC AAA TAT GAC GAC ATC A-3', GAPDH (reverse): 5'-GTA GCC CAG GAT GCC TTT GAG-3', GAPDH TaqMan probe: 5'-TCC CTC CGA TGC CTG CTT CAC TAC CTT-3') [54] and cyclophyllin A (Prod. No. Cf03986523-gH, Applied Biosystems, Foster City,
CA, USA) served as reference genes, and autoclaved water instead of cDNA was used as negative control.

\section{Immunohistochemistry}

An indirect immunoperoxidase method was used on tissue samples collected from pregnant dogs according to Kowalewski et al. [54]. For the detection of Lep, a rabbit polyclonal affinity purified antibody directed against the N-terminal region of the human leptin (ARP41697_P050, Aviva Systems Biology, San Diego, USA) diluted 1:200 was used, and for LepR, a goat polyclonal affinity purified antibody raised against a peptide mapping at the $\mathrm{C}$-terminus of the short form of LepR of mouse origin and recommended for the detection of both short and long LepR isoforms (Ob-R (M-18): sc-1834, Santa Cruz Biotechnology Inc., CA, USA) diluted 1:50. Briefly, 2-3 $\mu$ m thick sections of $\mathrm{Ut} / \mathrm{Pl}$ and uterine tissues were mounted on SuperFrost Plus microscope slides (Menzel-Gläser, Braunschweig, Germany), deparaffinized in xylol and rehydrated in a graded ethanol series. Antigen retrieval was achieved by heat induction, incubating slides in $10 \mathrm{mM}$ citrate buffer (pH 6.0) for $15 \mathrm{~min}$ at $100^{\circ} \mathrm{C}$. Endogenous peroxidase activity was quenched with $0.3 \%$ hydrogen peroxide in methanol. Non-specific binding sites were blocked with $10 \%$ goat serum (for Lep; KPL, Gaithersburg, USA) or $10 \%$ horse serum (for LepR; Vector Laboratories, Burlingame, USA). Slides were incubated with the primary antibodies overnight at $4^{\circ} \mathrm{C}$. Biotinylated goat antirabbit IgG and horse anti-goat IgG (Vector Laboratories, Burlingame, USA) at a dilution of 1:100 were used as secondary antibodies for Lep and LepR, respectively. Signals were enhanced using the avidin/biotinylated peroxidase complex (Vectastain ABC Kit, Vector Laboratories, Burlingame, USA) and color reactions were achieved by applying 3,3'-diaminobenzidine (DAB) as chromogen substrate (Liquid DAB+ substrate Kit, Dako Schweiz AG, Baar, Switzerland). Finally, slides were counterstained with Mayer's hematoxylin, dehydrated in a graded ethanol series and covered with coverslips. Isotype controls were carried out with pre-immune rabbit (for Lep) and goat (for LepR) IgG (Vector Laboratories, Burlingame, USA). Murine ovaries with corpora lutea were used as positive controls for both Lep and LepR.

\section{In situ hybridization (ISH)}

A non-radioactive method [55] was used for tissue localization of Lep and LepR mRNA in representative samples of Ut and Ut/Pl. Templates for cRNA probe synthesis were generated by the following canine-specific primers: Lep (forward) - 5'-ATG CGT TGT GGA CCT CTG TG-3', Lep (reverse) - 5'-GGT TGG AGC CCA GGA ATG AA-3', amplicon length 203 bp; LepR (forward) - 5'-CAT GGT GGG TGA CCG TGT TA-3', LepR (reverse) - 5'-TCC CTC GAG TGA TTG GAT TGC-3', 
amplicon length $232 \mathrm{bp}$. PCR products were separated on a $2 \%$ ethidium bromide-stained agarose gel, purified with the Qiaex II gel extraction system (Qiagen GmbH, Hilden, Germany) and cloned into a pGEM-T plasmid (Promega, Dübendorf, Switzerland). The plasmid clones containing the inserts were digested with restriction enzymes $\mathrm{NcoI}$ and NotI (New England Biolabs, Frankfurt, Germany) to obtain antisense and sense cRNA probes, respectively, which were labelled with digoxigenin (DIG-RNA labelling kit, Roche Diagnostics AG, Rotkreuz, Switzerland). Dotblot analysis was carried out with serially diluted DIGlabeled cRNA on a positively charged nylon membrane (Roche Diagnostics) for semi-quantitation of labeled cRNA concentration. Paraffin-embedded cross sections of $\mathrm{Ut}$ and $\mathrm{Ut} / \mathrm{Pl}$ were dewaxed, rehydrated, digested with $70 \mu \mathrm{g} / \mathrm{ml}$ proteinase $\mathrm{K}$ (Sigma-Aldrich Chemie $\mathrm{GmbH}$ ) and post-fixed with $4 \%$ paraformaldehyde. Hybridization was carried out overnight at $37^{\circ} \mathrm{C}$ in a formamide chamber. Signals for Lep and LepR mRNA were detected by DIGlabelled cRNA probes and alkaline phosphate-conjugated sheep anti-DIG Fab fragments (Roche Diagnostics AG, Rotkreuz, Switzerland) diluted 1:5000 in 1\% ovine serum.

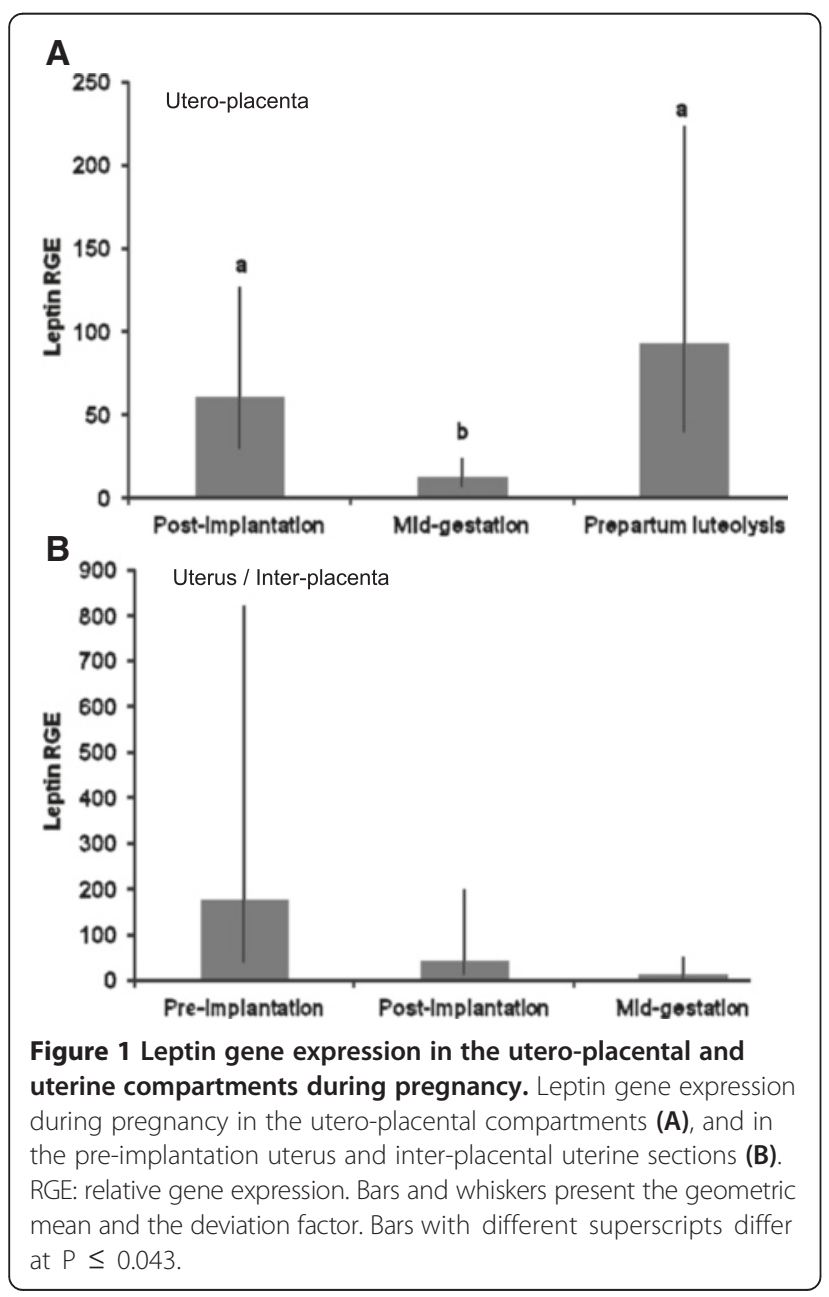

Color visualization was performed with 5-bromo-4chloro-3-indolyl phosphate in the presence of nitroblue tetrazolium (NBT/BCIP; Roche Diagnostics AG, Rotkreuz, Switzerland).

\section{Statistical analysis}

Only valid data on Lep and LepR gene expression were considered, where the relative amount of reference genes for a sample were constant (i.e., similar in the duplicate samples). Relative gene expression (RGE) was calculated by the $\Delta \Delta \mathrm{Ct}$ method as described [54,56]. Logarithmic transformation was performed when observed data were not normally distributed (Kolmogorov-Smirnov test, $\mathrm{P}<$ 0.05). A parametric one-way ANOVA followed by Tukey Honestly Significant Difference was used to compare RGE of Lep and LepR among pregnancy stages and after aglepristone treatment. We performed paired $t$-test or Wilcoxon signed-rank test for the comparison of Lep or LepR mRNA expression between the Ut/Pl and the Ut in the postimplantation and mid-gestation stages. Results are presented

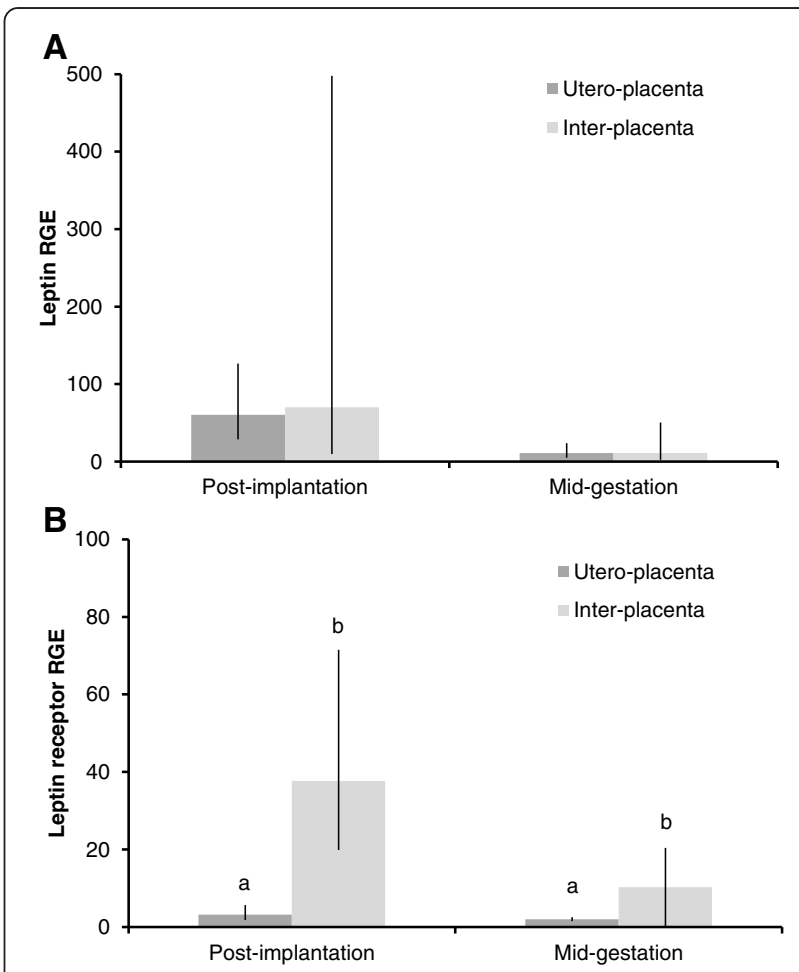

Figure 2 Comparison of leptin and leptin receptor gene expression between utero-placental and inter-placental uterine sections. Relative gene expression of leptin (A) and leptin receptor (B) between utero-placental and inter-placental uterine sections at post-implantation and at mid-gestation. RGE: relative gene expression. Bars and whiskers present the geometric mean and the deviation factor, or the mean and standard deviation of observed data in case of mid-gestation leptin receptor gene expression. Bars with different superscripts within the same pregnancy stage differ at $\mathrm{P}=0.003$ (post-implantation) and $\mathrm{P}=0.043$ (mid-gestation). 
as mean \pm standard deviation of observed data or geometric mean \pm deviation factor in the case of ln-transformed data. Level of significance was set at $\mathrm{P} \leq 0.05$; statistical calculations were carried out with IBM $^{\circledR}$ SPSS $^{\circledR}$ Statistics for Windows, Version 19.0 (Armonk, NY, USA).

\section{Results}

Lep in the Ut/PI and Ut

Lep gene expression during pregnancy and after aglepristone induced abortion

In the $\mathrm{Ut} / \mathrm{Pl}$, we found lower Lep mRNA concentrations at mid-gestation than at post-implantation and prepartum luteolysis $(\mathrm{P} \leq 0.043$; Figure $1 \mathrm{~A})$. In the $\mathrm{Ut}$, Lep expression did not change throughout gestation $(P=0.12$; Figure $1 B)$. Lep mRNA levels were similar between the Ut/Pl and Ut both at the post-implantation $(\mathrm{P}=0.87)$ and mid-gestation stages ( $\mathrm{P}=1.00$; Figure $2 \mathrm{~A})$.

Induction of abortion with aglepristone in mid-gestation did not affect Lep gene expression in the Ut/Pl $(\mathrm{P}=0.54)$, but lower levels were detected in the Ut at $72 \mathrm{~h}$ than at $24 \mathrm{~h}$ after the second aglepristone injection $(\mathrm{P}=0.05$; Figure $3 \mathrm{~A})$.

\section{Immunohistochemical detection of Lep during pregnancy}

In the Ut, Lep immunoreactivity was detected in the surface epithelium and superficial endometrial glands (Figure 4A). Weaker positive signals were present in the epithelium of deep uterine glands at pre- and post-implantation, but at mid-gestation, they became stronger in the deep glands but were variably present in the endometrial stroma (Figure 4C).

In the Ut/Pl, fetal trophoblasts of the placental labyrinth stained positively for Lep, and maternal decidual cells had weaker signals at all pregnancy stages (Figure 5A,C). Invading trophoblast cells surrounding large maternal vessels at the base of the placental labyrinth showed intense immunoreactivity (Figure 5C inset). Epithelial cells of the glandular chambers stained weakly with signals present also in the stroma (Figure 5E).

Lep was also detected in smooth muscle cells of the myometrium (Figures 4A upper right inset and 5E inset) and of blood vessels, and sporadically in the endothelium (Figures $4 \mathrm{~A}, \mathrm{C}$ and $5 \mathrm{~A}, \mathrm{C}$ ).
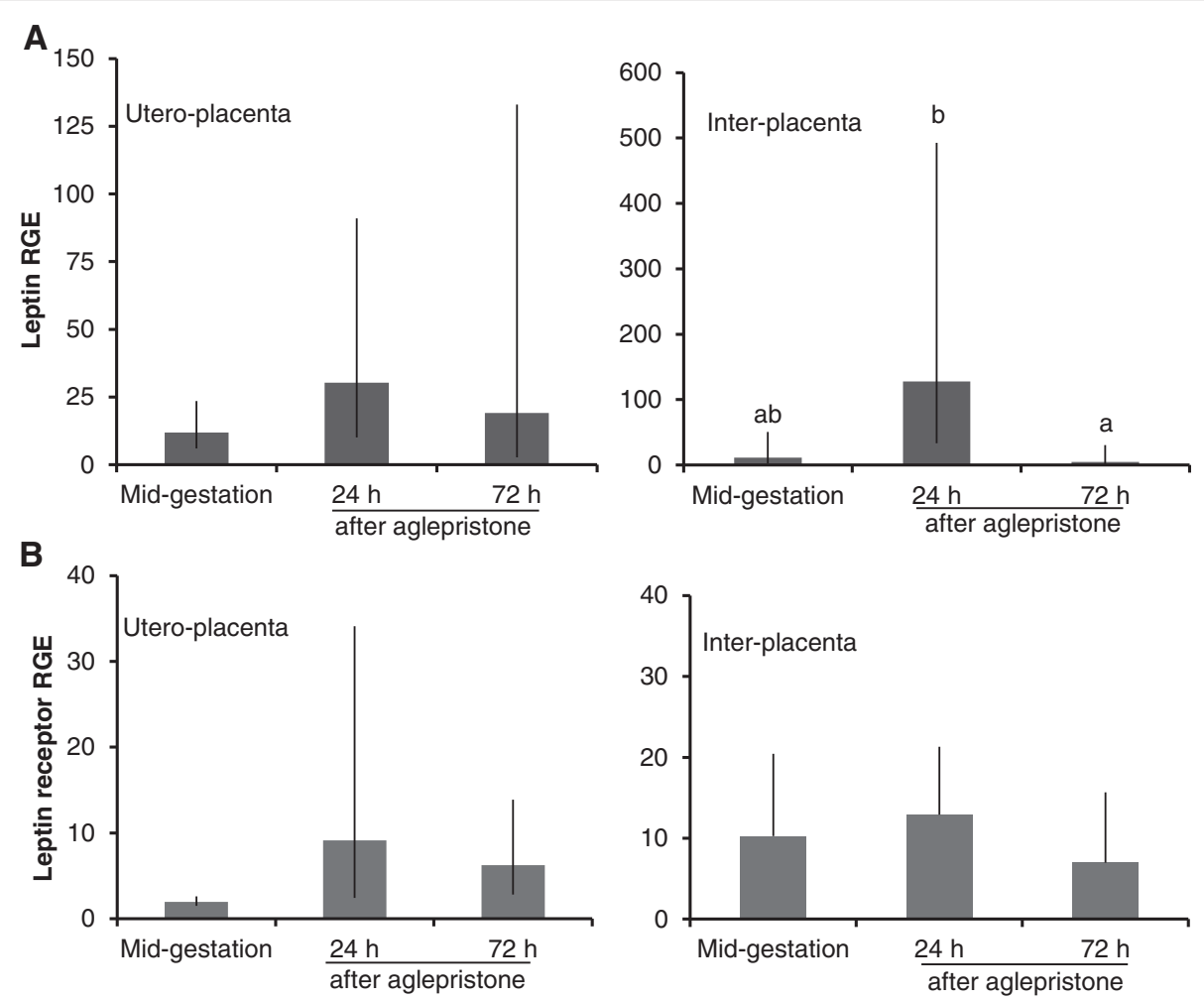

Figure 3 Leptin and leptin receptor gene expression in the utero-placental and uterine compartments after abortion induced with aglepristone. Leptin gene expression (A) in utero-placental compartments and inter-placental uterine sections at mid-gestation, 24 and $72 \mathrm{~h}$ after aglepristone administration. Leptin receptor gene expression (B) in the utero-placental compartments and inter-placental uterine sections at mid-gestation, 24 and $72 \mathrm{~h}$ after aglepristone administration. RGE: relative gene expression. Bars and whiskers present the geometric mean and the deviation factor or the mean and standard deviation of observed data in case of inter-placental leptin receptor gene expression. Bars with different superscripts differ at $\mathrm{P}=0.05$. 


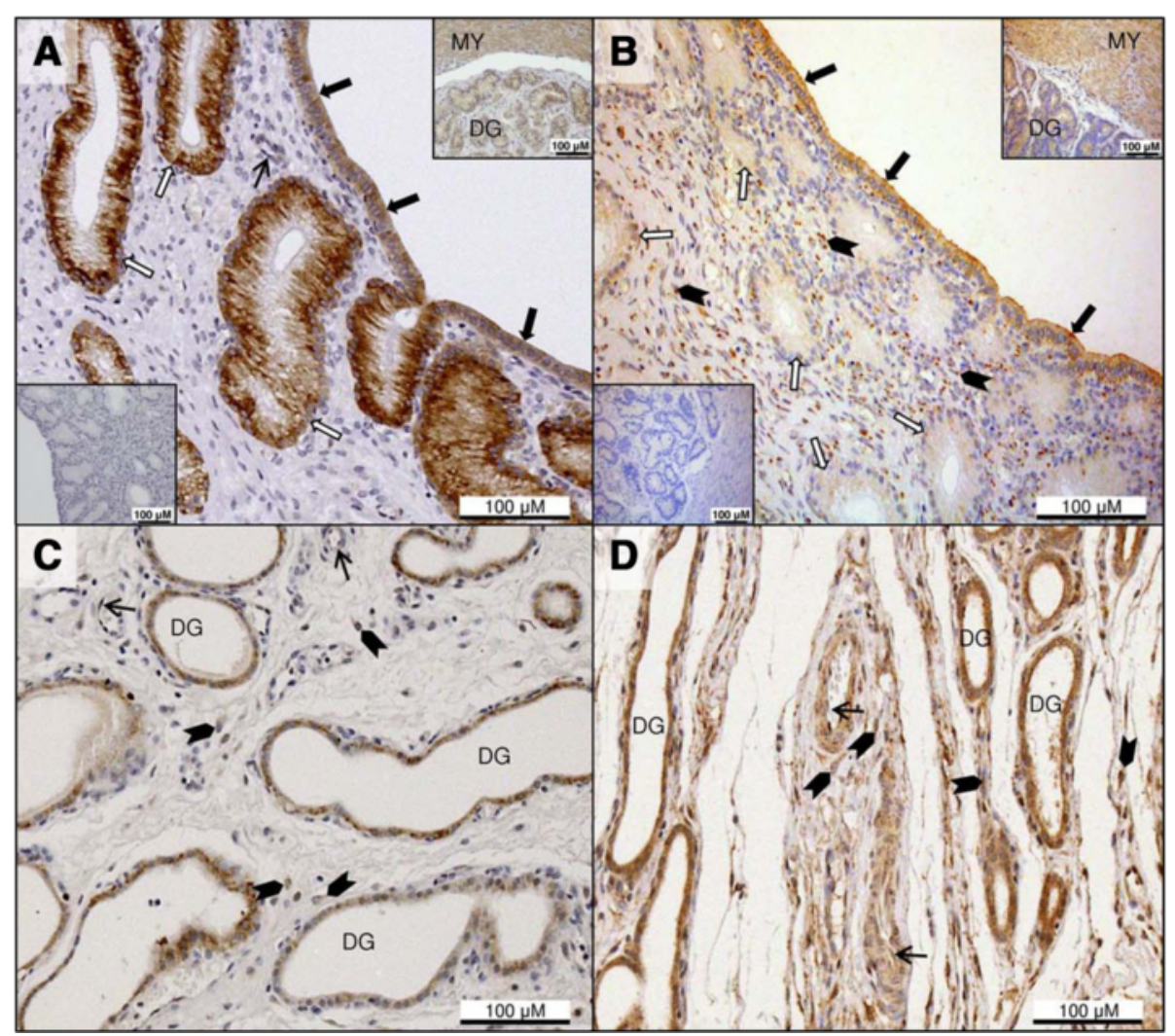

Figure 4 Immunohistochemical detection of leptin and leptin receptor in the pre-implantation uterus and inter-placental sections during pregnancy. Immunohistochemical localization of leptin (Lep; A, C) and leptin receptor (LepR; B, D) in pre-implantation and inter-placental uterine sections (Ut) during pregnancy. (A) Lep immunostaining at pre-implantation is present in the luminal epithelium (solid arrows) and in the superficial glands (open arrows); endothelial cells stain occasionally (thin arrow). The myometrium and deep uterine glands also show positive reaction for Lep (inset upper right); inset (lower left) indicates the isotype control for Lep. (B) LepR immunoreactivity in the Ut at pre-implantation is noted in the surface epithelium (solid arrows), and in the endometrial stroma close to the lumen (solid arrowheads). Superficial glands (open arrows) stain weakly, and the myometrium and deep uterine glands also show positive signals (inset upper right); inset (lower left) shows the isotype control for LepR. (C) Strong Lep staining is visible in the deep uterine glands at mid-gestation; stromal signals are also evident (solid arrowheads), while endothelial cells show sporadic, weak signals (thin arrows). (D) At mid-gestation, the epithelium of deep uterine glands has stronger LepR immunoreactivity than at pre-implantation. Stromal signals are still present (solid arrowheads), and signals are also found occasionally in the endothelium (thin arrows). DG: deep uterine glands, MY: myometrium.

\section{In situ hybridization for Lep}

In the Ut, Lep mRNA was found in the luminal and glandular epithelial cells of the endometrium (Figure 6A). In the Ut/Pl, fetal trophoblasts within the placental labyrinth gave stronger signals than decidual cells (Figure 6C), while the epithelium of the glandular chambers and deep uterine glands stained weakly (not shown). Strong positive signals were also detected in the myometrium (Figure 6A upper right inset and $6 \mathrm{C}$ upper right inset), and occasionally in blood vessel endothelium (Figure 6C).

\section{LepR in the Ut/PI and $\mathrm{Ut}$}

LepR gene expression during pregnancy and after aglepristone induced abortion

LepR expression in the Ut/Pl increased at the time of prepartum luteolysis compared to the post-implantation and mid-gestation stages $(\mathrm{P}<0.001$; Figure $7 \mathrm{~A})$. In the Ut, LepR mRNA concentrations were higher at pre- and postimplantation than at mid-gestation $(\mathrm{P} \leq 0.019$; Figure $7 \mathrm{~B})$. LepR expression was significantly down-regulated in the $\mathrm{Ut} / \mathrm{Pl}$ compared to the Ut at post-implantation $(\mathrm{P}=0.003)$ and at mid-gestation $(\mathrm{P}=0.043$; Figure $2 \mathrm{~B})$.

After aglepristone treatment, LepR mRNA levels in the $\mathrm{Ut} / \mathrm{Pl}$ and Ut (Figure $3 \mathrm{~B}$ ) were similar at all time-points compared to the mid-gestation stage $(\mathrm{P}=0.06$ and $\mathrm{P}=$ 0.63 , respectively).

\section{Immunohistochemical detection of LepR during pregnancy}

Strong positive staining for LepR was visible in the uterine surface epithelium, and the superficial and deep uterine glands also showed positive reaction. Stromal signals were 


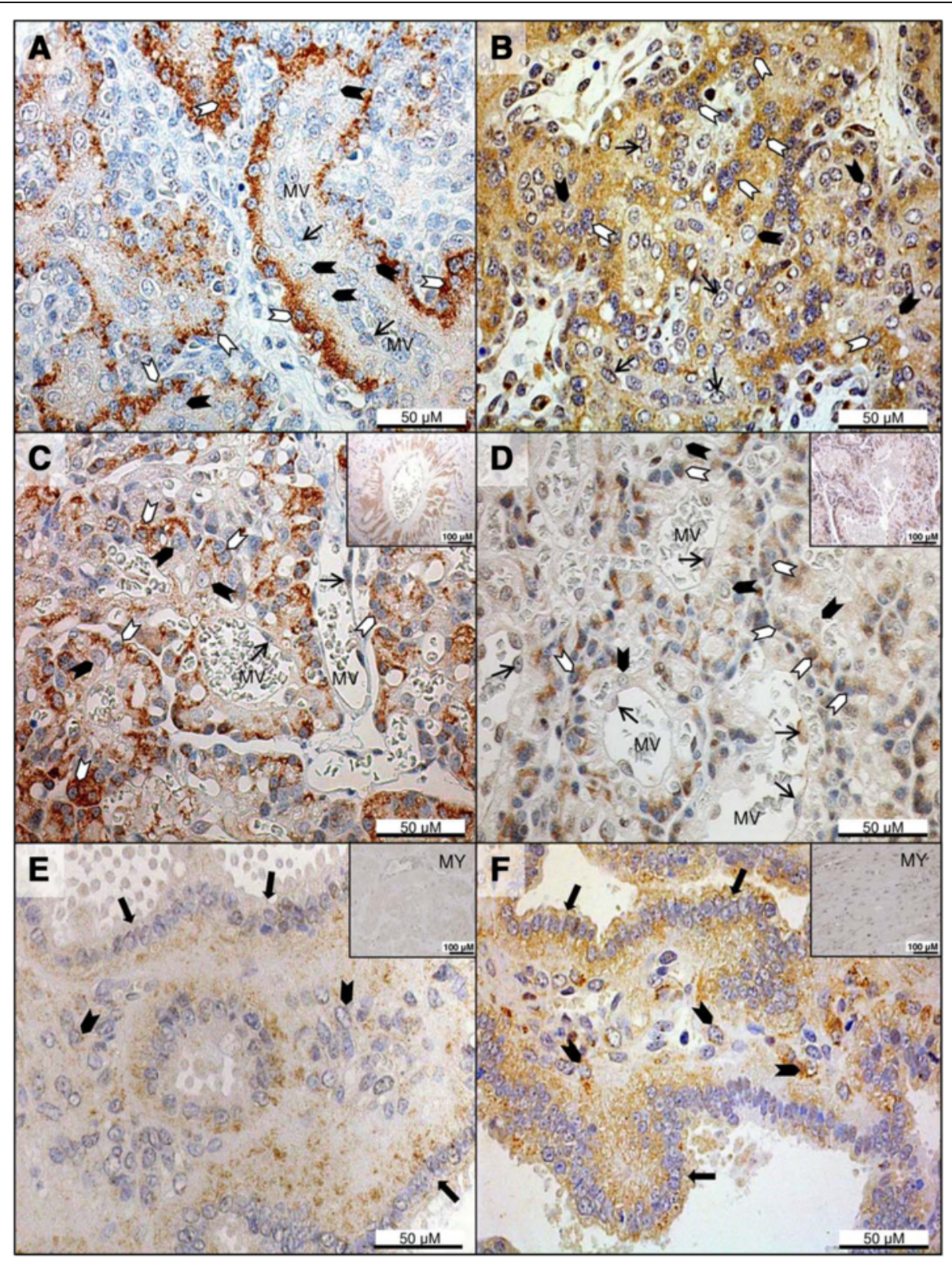

Figure 5 Immunohistochemical detection of leptin and leptin receptor in the utero-placental compartments during pregnancy. Immunohistochemical localization of leptin (Lep; A, C, E) and leptin receptor (LepR; B, D, F) in the utero-placental compartments (Ut/Pl) during pregnancy. (A) Lep signals are strong in fetal trophoblast cells (open arrowheads) of the placental labyrinth at mid-gestation, while maternal decidual cells (solid arrowheads) stain more weakly and blood vessel endothelial cells (thin arrows) show sporadic signals. (B) LepR positive trophoblasts (open arrowheads) are present in the placental labyrinth at mid-gestation. LepR immunoreactivity is less intense in decidual cells (solid arrowheads) and in blood vessel endothelium (thin arrows). (C) Strong Lep immunoreactivity is evident in fetal trophoblast cells (open arrowheads) of the placental labyrinth at prepartum luteolysis with weaker signals in decidual cells (solid arrowheads) and occasional staining in the endothelium (thin arrows). Intense signals are detected in trophoblasts at the base of the labyrinth invading large maternal vessels (inset). (D) LepR positive trophoblast cells (open arrowheads) are shown in the placental labyrinth at prepartum luteolysis with less intense staining in maternal decidual cells (solid arrowheads) and blood vessel endothelium (thin arrows). The inset shows positive reaction in fetal trophoblast cells invading large maternal vessels at the base of the labyrinth. (E) Lep staining is present in the epithelial cells of the glandular chambers (solid arrows) and sporadic signals are also visible in the stroma (solid arrowheads). Positive staining in the myometrium is shown in the inset. (F) In the glandular chambers, epithelial cells stain positive for LepR (solid arrows) and stromal signals (solid arrowheads) are also present. Positive immunoreactivity in the myometrium is presented in the inset. MV: maternal vessel, MY: myometrium. 


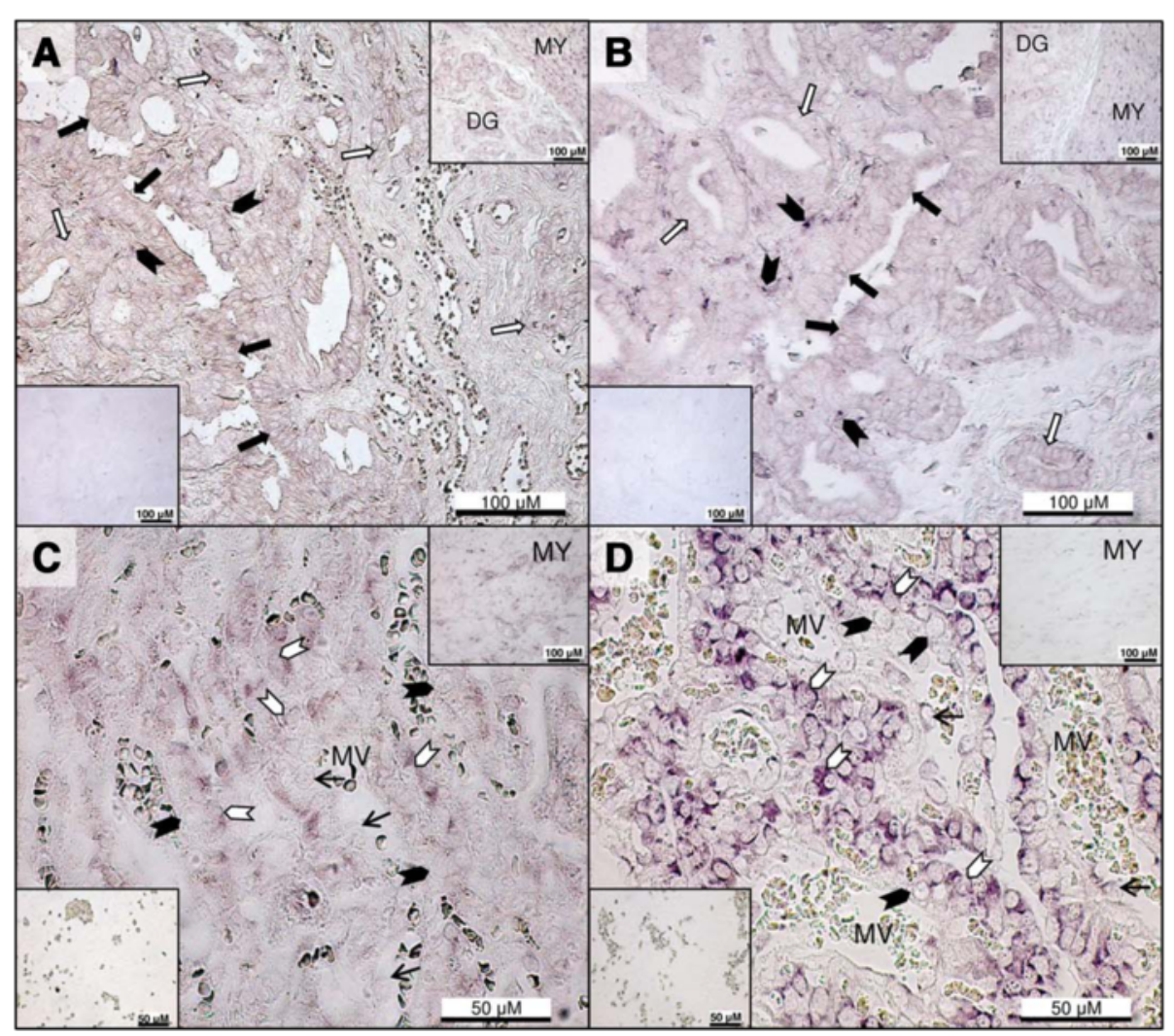

Figure 6 In situ hybridization for leptin and leptin receptor in the inter-placental uterus and utero-placental compartments during pregnancy. Localization of leptin (Lep) and leptin receptor (LepR) mRNA by in situ hybridization in inter-placental sections (Ut) at post-implantation (A, B), and in the utero-placental compartments (Ut/Pl) at prepartum luteolysis (C, D). (A) Lep mRNA expression is evident in the surface epithelium (solid arrows) and superficial glandular epithelium (open arrows) with weak sub-epithelial stromal signals (solid arrowheads). Deep uterine glands and the myometrium also stain positively for Lep (inset upper right). A negative control is shown in the lower left inset. (B) LepR mRNA is expressed in the luminal epithelium (solid arrows) and superficial glandular epithelial cells (open arrows). Note the prominent stromal signals (solid arrowheads) close to the lumen. The upper right inset is positive staining for LepR in the deep uterine glands and myometrium, and the lower left inset shows a negative control. (C) Intense Lep expression is noted in the fetal trophoblast cells (open arrowheads) of the placental labyrinth at prepartum luteolysis, in contrast to weak staining in maternal decidual cells (solid arrowheads) and sporadic signals in blood vessel endothelium (thin arrows); the upper right inset shows positive reaction in the myometrium, and the lower left inset is the negative control sense probe for Lep. (D) LepR mRNA expression is strong in the placental labyrinth at prepartum luteolysis within fetal trophoblast cells (open arrowheads), while decidual cells have less intense signals (solid arrowheads) and endothelial cells (thin arrows) stain occasionally; the upper right inset shows LepR mRNA in the myometrium, and the lower left inset presents the negative control sense probe for LepR. DG: Deep uterine glands, MY: Myometrium, MV: maternal vessel.

evident in the endometrium close to the lumen, especially in the pre-implantation group (Figure 4B). In later pregnancy stages, the glandular epithelium stained relatively more intensely than at pre-implantation (Figure 4D).

In the Ut/Pl, LepR signals were evident in fetal trophoblast cells of the placental labyrinth, while maternal decidual cells stained more weakly at all pregnancy stages (Figure 5B,D). LepR immunoreactivity was especially strong in the trophoblasts invading large maternal vessels at the base of the labyrinth (Figure 5D, inset). In the glandular chambers, LepR protein was detected in the epithelial cells as well as in the stroma (Figure 5F). Deep uterine glands of the Ut/Pl also showed positive signals (not shown).
The myometrium (Figures 4B upper right inset and 5F inset), blood vessel media, and sporadically also blood vessel endothelial cells (Figures 4D and 5B,D), all stained positive for LepR in the Ut and Ut/Pl.

\section{In situ hybridization for LepR}

In the post-implantation Ut, LepR mRNA was present in the surface and glandular epithelial cells with strong signals in the endometrial stroma close to the luminal epithelium (Figure 6B).

In the $\mathrm{Ut} / \mathrm{Pl}$ at prepartum luteolysis, strong LepR mRNA expression was detected in the fetal trophoblasts of the placental labyrinth (Figure 6D), while decidual cells (Figure 6D) and epithelial cells of the glandular chambers 


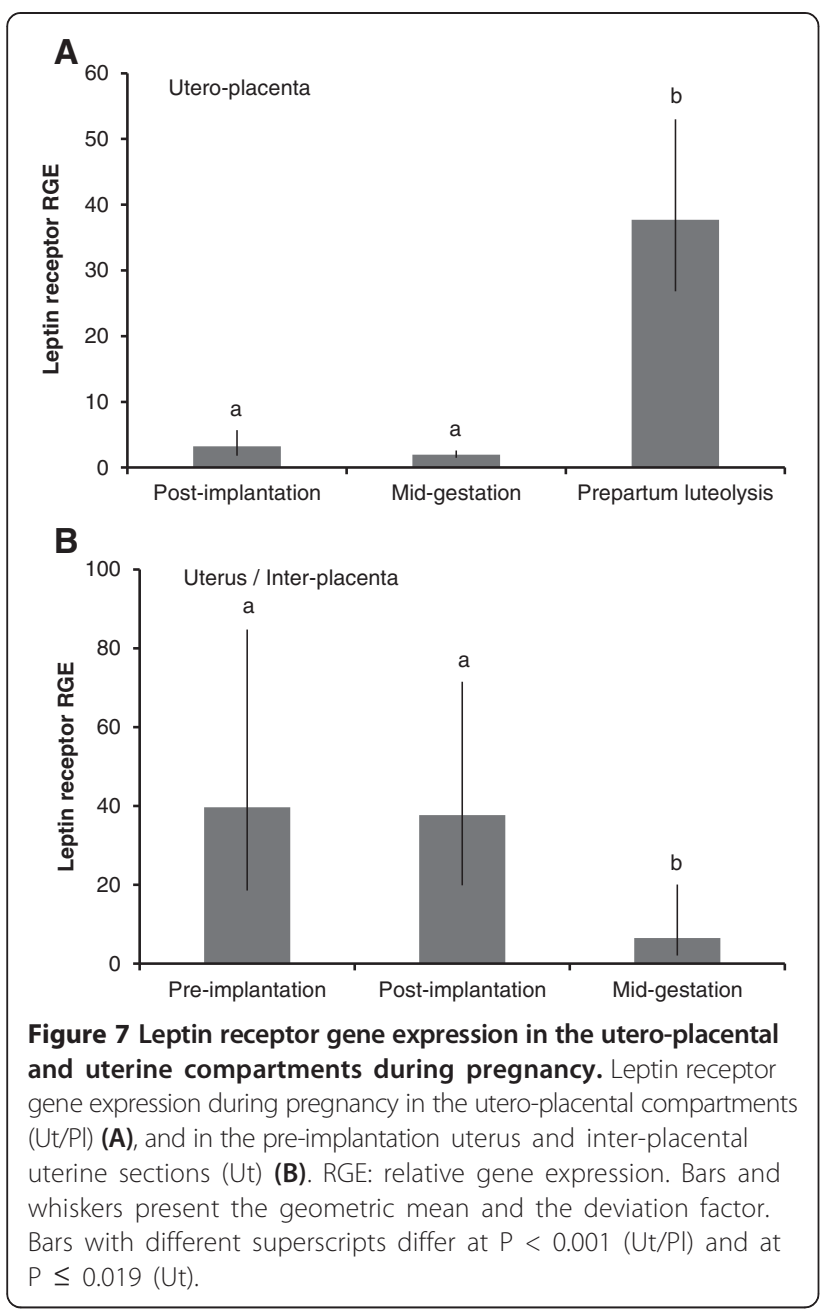

and deep uterine glands showed weaker reactivity. Positive signals were also present in the myometrium (Figure 6B upper right inset and Figure 6D upper right inset), and sporadically in blood vessel endothelial cells (Figure 6D).

\section{Discussion}

We found that in the Ut, LepR expression was up-regulated at pre- and post-implantation compared to mid-gestation but Lep expression did not change. Additionally, LepR and Lep were co-localized in the glandular epithelium and in the luminal epithelial cells of the Ut, which is in direct contact with the early canine embryo. In the studies of Kitawaki et al. [57] and Cervero et al. [5], LepR expression in the human endometrium increased gradually from the proliferative to the early or mid-late secretory phase coinciding with the time of uterine receptivity and implantation. Protein signals for LepR and Lep in the uteri of women were predominantly localized in the luminal epithelium, in the endometrial glands and in stromal cells [3], which is in accordance with our study. Bartel et al. [50] also described immunoreactivity for both proteins in the surface and glandular epithelium, and occasional Lep staining in the stromal parts of the endometrium during diestrus and anestrus in non-pregnant dogs, but the date of ovulation was not known. In contrast to our study, Schäfer-Somi et al. [37] and Beceriklisoy et al. [39] did not detect Lep mRNA expression by qualitative PCR in the uterus of non-pregnant bitches in early diestrus or in pregnant dogs at pre-implantation and at d 20-35 of gestation. In the same study [37], Lep mRNA was not found in pre-implantation canine embryos either, while Lep protein and LepR protein and mRNA expression were not evaluated. The discrepancy between these reports and ours regarding uterine and utero-placental Lep expression may be due to methodology, because the semiquantitative real-time (TaqMan) PCR used here is more sensitive than the qualitative approach. The expression/ secretion of downstream molecular markers of endometrial receptivity, e.g., adhesion molecules ( $\beta 3$ integrin) and cytokines (LIF, IL-1 and their receptors), was also increased after treatment of human endometrial epithelial cells with Lep [25,26]. In bitches, the expression of integrins is higher in the uterus of early pregnant than reproductive stage-matched non-pregnant diestrous animals [58]. Our findings therefore suggest that the Lep signaling pathway may be involved in the early embryo-maternal cross-talk in the dog.

A role for LepR in the canine implantation/placentation process may be hypothesized after our study found decreased LepR mRNA levels at placentation sites compared to the inter-placental uterus. In mice, LepR down-regulation at implantation sites was previously shown by global gene expression analysis [59], and Yoon et al. [60] also detected increased LepR expression at inter-implantation compared to implantation sites in mouse uteri. This hypothesis is further supported by the results of a recent study [61] in which women with recurrent implantation failure had lower endometrial Lep and higher LepR expression compared to fertile controls. These data indicate that, as in other species, decreased LepR expression at the placentation site may also be crucial for successful implantation and placentation in bitches.

Increased Lep expression in the Ut/Pl at post-implantation compared to mid-gestation may further point to a possible role for Lep during implantation and placenta formation in the dog. The localization of Lep and LepR protein and mRNA in fetal trophoblast cells in our study is in agreement with previous data on women, mice, pigs and cats [22,62-67], and may imply an autocrine/paracrine effect. The positive role of Lep was evidenced previously in human and murine models in vitro, where Lep promoted fetal trophoblast cell invasion via MMP-2 and -9 , and Lep also showed its mitogenic potential [22-24,68,69]. Taken together, a regulatory, perhaps stimulatory role for Lep on trophoblast cell migration and proliferation during 
the process of canine implantation and placentation may be likely however this cannot be definitely concluded from our data.

Even though the reason for the prepartum up-regulation of utero-placental Lep and LepR is still not clear, it could imply a physiological role in canine parturition. Lep is a pro-inflammatory cytokine showing structural similarities to the type I cytokine superfamily [70] and may have an immune-modulatory function before and during labor. In women, serum Lep levels were positively correlated with other cytokines, e.g., IL-6, interferon- - -inducible protein and C-reactive protein in late pregnancy [71]. During induced parturition, plasma Lep concentrations increased and were higher in women after spontaneous delivery than after Cesarean section without labor. Similarly, Lep expression in the placenta after natural birth was also higher than after Cesarean section [72]. A stimulatory effect of Lep on pro-inflammatory mediators was shown by Lappas et al. [73], where prostaglandin F2 $\alpha$ (PGF2 $\alpha$ ), prostaglandin E2, IL-1 $\beta$, IL- 6 and TNF $\alpha$ release was increased after in vitro treatment of term human placentas with Lep. In dogs, the source of the PGF $2 \alpha$ rise before birth seems to be the placenta, where enzymes of prostaglandin biosynthesis (cyclooxygenase 2, prostaglandin E synthase) are up-regulated prepartum [41]. In our study, the significant increase in Lep and LepR expression in the Ut/Pl at prepartum luteolysis and their localization within those cells, where members of the prostaglandin synthesis pathway were also found [41], may suggest an autocrine/ paracrine regulatory role for Lep in the events leading to parturition in the bitch.

The glandular epithelium was also a site of Lep and LepR expression both in the Ut and Ut/Pl. An autocrine/ paracrine function regulating endometrial secretory capacity and thus histiotrophe production may be likely.

In pigs, myometrial expression of Lep and LepR transcript and protein were detected both in the luteal phase of the cycle and during pregnancy $[65,66]$. We also found Lep and LepR in the muscle layer of the canine uterus during all pregnancy stages, and therefore it seems that they are normal constituents of the myometrium. Because in our experiments full thickness Ut and Ut/Pl tissues were used, the degree of independent contribution of the myometrium, endometrium or placental labyrinth to the detected changes in Lep and LepR gene expression levels cannot be ascertained without further compartmentalization studies. Certain tissue layers may have contributed differently at given time points over the course of gestation, according to their specific role in the endocrine and physiological events, e.g., during implantation or parturition. Furthermore, an increasing mass of the placental labyrinth with advancing pregnancy could have altered, at least to some extent, the ratio of the uterine compartments at placentation sites.
The LepR antibody used here identifies both the long and short isoforms of the receptor, which differ in their ability of signal transduction. While all transmembrane receptor isoforms can activate the tyrosine kinase Janus kinase (JAK2), only the long isoform with a full-length intracellular domain has signal transducer and activator of transcription (STAT)-binding sites and is able to activate the main signalling cascade JAK2/ STAT3. However, the short isoforms are also capable of signalling through various intracellular pathways and mediate Lep's actions (reviewed by $[74,75]$ ). Therefore, the long and short LepR isoforms are relevant to investigate even though the long isoform is of particular interest, and studies on the expression/function of the different LepR splice variants in the dog could be planned.

In a few animals in our study, Lep and/or LepR mRNA expression was not detected in the Ut or $\mathrm{Ut} / \mathrm{Pl}$, which might have been due to degradation of RNA, sensitivity of our assay, individual differences in expression levels or pregnancy stage.

\section{Conclusions}

The canine uterus and placenta are sources of Lep and targets of its actions during gestation. Lep and LepR are differentially expressed in these tissues over the course of pregnancy, and their presence in various cells types indicates multiple paracrine/autocrine functions. Lep and LepR are expressed both in the fetal and maternal sides of the placenta; thus, a role in placental physiology and fetomaternal cross-talk seems likely. The Lep signaling system may be one of the pathways involved in the establishment and maintenance of pregnancy, and may also play a regulatory role in parturition in the bitch.

\section{Competing interests}

The authors declare that they have no competing interests.

\section{Authors' contributions}

OB designed the study, carried out PCR, ISH and part of the IHC, analyzed and interpreted the data, and wrote the manuscript. LPS performed the IHC, contributed to data analysis and interpretation, and revised the manuscript. AG helped with ISH, contributed to data interpretation and revised the manuscript. $A B$ contributed to critical discussions on the data and interpretation, and revised the manuscript. MPK contributed to study design, advised on laboratory procedures and data interpretation, and revised the manuscript. IMR contributed to study design, advised on data evaluation and interpretation, revised and edited the manuscript. All authors read and approved the final manuscript.

\section{Acknowledgements}

The authors thank Elisabeth Högger and Urs Büchler for their technical help We are grateful to Dr. Monika Hilbe and Dr. Elisabeth Eppler for advice and discussions on immunohistochemistry.

\section{Author details}

${ }^{1}$ Clinic of Reproductive Medicine, Vetsuisse-Faculty, University of Zurich, Winterthurerstrasse 260, 8057 Zurich, Switzerland. ${ }^{2}$ Institute of Veterinary Anatomy, Vetsuisse-Faculty, University of Zurich, Winterthurerstrasse 260, 8057 Zurich, Switzerland. 
Received: 6 October 2014 Accepted: 6 February 2015

\section{Published online: 08 March 2015}

\section{References}

1. Kielar D, Clark JS, Ciechanowicz A, Kurzawski G, Sulikowski T, Naruszewicz M. Leptin receptor isoforms expressed in human adipose tissue. Metabolism. 1998:47:844-7.

2. Jin L, Burguera BG, Couce ME, Scheithauer BW, Lamsan J, Eberhardt NL, et al. Leptin and leptin receptor expression in normal and neoplastic human pituitary: evidence of a regulatory role for leptin on pituitary cell proliferation. J Clin Endocrinol Metab. 1999;84:2903-11.

3. González RR, Caballero-Campo P, Jasper M, Mercader A, Devoto L, Pellicer A, et al. Leptin and leptin receptor are expressed in the human endometrium and endometrial leptin secretion is regulated by the human blastocyst. J Clin Endocrinol Metab. 2000;85:4883-8.

4. Ryan NK, Woodhouse CM, Van der Hoek KH, Gilchrist RB, Armstrong DT, Norman RJ. Expression of leptin and its receptor in the murine ovary: possible role in the regulation of oocyte maturation. Biol Reprod. 2002;66:1548-54

5. Cervero A, Horcajadas JA, Martín J, Pellicer A, Simón C. The leptin system during human endometrial receptivity and preimplantation development. J Clin Endocrinol Metab. 2004;8:2442-51.

6. Martos-Moreno GA, Chowen JA, Argente J. Metabolic signals in human puberty: effects of over and undernutrition. Mol Cell Endocrinol. 2010;324:70-81.

7. Herrid M, Palanisamy SK, Ciller UA, Fan R, Moens P, Smart NA, et al. An updated view of leptin on implantation and pregnancy: a review. Physiol Res. 2014;63:543-57.

8. Hardie L, Trayhurn P, Abramovich D, Fowler P. Circulating leptin in women: a longitudinal study in the menstrual cycle and during pregnancy. Clin Endocrinol (Oxf). 1997;47:101-6.

9. Gavrilova O, Barr V, Marcus-Samuels B, Reitman M. Hyperleptinemia of pregnancy associated with the appearance of a circulating form of the leptin receptor. J Biol Chem. 1997;272:30546-51.

10. Amico JA, Thomas A, Crowley RS, Burmeister LA. Concentrations of leptin in the serum of pregnant, lactating, and cycling rats and of leptin messenger ribonucleic acid in rat placental tissue. Life Sci. 1998;63:1387-95.

11. Berg EL, McNamara DL, Keisler DH. Endocrine profiles of periparturient mares and their foals. J Anim Sci. 2007:85:1660-8.

12. Tessier DR, Ferraro ZM, Gruslin A. Role of leptin in pregnancy: consequences of maternal obesity. Placenta. 2013;34:205-11.

13. Hoggard N, Hunter L, Duncan JS, Williams LM, Trayhurn P, Mercer JG. Leptin and leptin receptor mRNA and protein expression in the murine fetus and placenta. Proc Natl Acad Sci U S A. 1997;94:11073-8.

14. Masuzaki H, Ogawa Y, Sagawa N, Hosoda K, Matsumoto T, Mise H, et al. Nonadipose tissue production of leptin: leptin as a novel placenta-derived hormone in humans. Nat Med. 1997;3:1029-33.

15. Jansson N, Greenwood SL, Johansson BR, Powell TL, Jansson T. Leptin stimulates the activity of the system $A$ amino acid transporter in human placental villous fragments. J Clin Endocrinol Metab. 2003;88:1205-11.

16. Mousiolis AV, Kollia P, Skentou C, Messinis IE. Effects of leptin on the expression of fatty acid-binding proteins in human placental cell cultures. Mol Med Rep. 2012;5:497-502.

17. Cao R, Brakenhielm E, Wahlestedt C, Thyberg J, Cao Y. Leptin induces vascular permeability and synergistically stimulates angiogenesis with FGF-2 and VEGF. Proc Natl Acad Sci U S A. 2001;98:6390-5.

18. Anagnostoulis S, Karayiannakis AJ, Lambropoulou M, Efthimiadou A, Polychronidis A, Simopoulos C. Human leptin induces angiogenesis in vivo. Cytokine. 2008:42:353-7.

19. Leiser R, Kaufmann P. Placental structure: in a comparative aspect. Exp Clin Endocrinol. 1994;102:122-34.

20. Staun-Ram E, Shalev E. Human trophoblast function during the implantation process. Reprod Biol Endocrinol. 2005;3:56.

21. Staun-Ram E, Goldman S, Gabarin D, Shalev E. Expression and importance of matrix metalloproteinase 2 and 9 (MMP-2 and -9 ) in human trophoblast invasion. Reprod Biol Endocrinol. 2004;2:59.

22. Castelucci M, De Matteis R, Meisser A, Cancello R, Monsurrò V, Islami D, et al. Leptin modulates extracellular matrix molecules and metalloproteinases: possible implications for trophoblast invasion. Mol Hum Reprod. 2000;6:951-8.
23. Gonzalez RR, Devoto L, Campana A, Bischof P. Effects of leptin, interleukin-1a, interleukin-6, and transforming growth factor $\beta$ on markers of trophoblast invasive phenotype: integrins and metalloproteinases. Endocrine. 2001:15:157-64.

24. Schulz LC, Widmaier EP. The effect of leptin on mouse trophoblast cell invasion. Biol Reprod. 2004;71:1963-7.

25. Gonzalez RR, Leavis P. Leptin upregulates beta3-integrin expression and interleukin-1 beta, upregulates leptin and leptin receptor expression in human endometrial epithelial cell cultures. Endocrine. 2001;16:21-8.

26. Gonzalez RR, Rueda BR, Ramos MP, Littell RD, Glasser S, Leavis PC. Leptin-induced increase in leukemia inhibitory factor and its receptor by human endometrium is partially mediated by interleukin 1 receptor signaling. Endocrinology. 2004;145:3850-7.

27. Kawamura K, Sato N, Fukuda J, Kodama H, Kumagai J, Tanikawa H, et al. Leptin promotes the development of mouse preimplantation embryos in vitro. Endocrinology. 2002;143:1922-31.

28. Herrid M, Nguyen VL, Hinch G, McFarlane JR. Leptin has concentration and stage-dependent effects on embryonic development in vitro. Reproduction. 2006;132:247-56

29. Lange Consiglio A, Dell'Aquila ME, Fiandanese N, Ambruosi B, Cho YS, Bosi $\mathrm{G}$, et al. Effects of leptin on in vitro maturation, fertilization and embryonic cleavage after ICSI and early developmental expression of leptin (Ob) and leptin receptor (ObR) proteins in the horse. Reprod Biol Endocrinol. 2009;7:113.

30. Ramos MP, Rueda BR, Leavis PC, Gonzalez RR. Leptin serves as an upstream activator of an obligatory signaling cascade in the embryo-implantation process. Endocrinology. 2005;146:694-701.

31. Sokolowski JH. The effects of ovariectomy on pregnancy maintenance in the bitch. Lab Anim Sci. 1971;21:696-9.

32. Concannon PW, Hansel W, Visek WJ. The ovarian cycle of the bitch: plasma estrogen, $\mathrm{LH}$ and progesterone. Biol Reprod. 1975;13:112-21.

33. Hoffmann B, Höveler R, Nohr B, Hasan SH. Investigations on hormonal changes around parturition in the dog and the occurrence of pregnancy-specific non conjugated oestrogens. Exp Clin Endocrinol. 1994;102:185-9.

34. Steinetz BG, Goldsmith LT, Lust G. Plasma relaxin in pregnant and lactating dogs. Biol Reprod. 1987:37:719-25.

35. Jöchle W. Prolactin in canine and feline reproduction. Reprod Domest Anim. 1997;32:183-93.

36. Onclin K, Murphy B, Verstegen JP. Comparisons of estradiol, LH and FSH patterns in pregnant and nonpregnant beagle bitches. Theriogenology. 2002;57:1957-72.

37. Schäfer-Somi S, Beceriklisoy HB, Budik S, Kanca H, Aksoy OA, Polat B, et al. Expression of genes in the canine pre-implantation uterus and embryo: implications for an active role of the embryo before and during invasion. Reprod Domest Anim. 2008;43:656-63.

38. Schäfer-Somi S, Klein D, Beceriklisoy HB, Sabitzer S, Ay SS, Agaoglu AR, et al. Uterine progesterone receptor and leukaemia inhibitory factor mRNA expression in canine pregnancy. Reprod Domest Anim. 2009;44 Suppl 2:109-14.

39. Beceriklisoy HB, Schäfer-Somi S, Kücükaslan I, Agaoglu R, Gültiken N, Ay SS, et al. Cytokines, growth factors and prostaglandin synthesis in the uterus of pregnant and non-pregnant bitches: the features of placental sites. Reprod Domest Anim. 2009:44 Suppl 2:115-9.

40. Kautz E, Gram A, Aslan S, Ay SS, Selçuk M, Kanca H, et al. Expression of genes involved in the embryo-maternal interaction in the early-pregnant canine uterus. Reproduction. 2014;147:703-17.

41. Kowalewski MP, Beceriklisoy HB, Pfarrer C, Aslan S, Kindahl H, Kücükaslan I, et al. Canine placenta: a source of prepartal prostaglandins during normal and antiprogestin-induced parturition. Reproduction. 2010;139:655-64.

42. Kowalewski MP, Michel E, Gram A, Boos A, Guscetti F, Hoffmann B, et al. Luteal and placental function in the bitch: spatio-temporal changes in prolactin receptor (PRLr) expression at dioestrus, pregnancy and normal and induced parturition. Reprod Biol Endocrinol. 2011;9:109.

43. Gram A, Büchler U, Boos A, Hoffmann B, Kowalewski MP. Biosynthesis and degradation of canine placental prostaglandins: prepartum changes in expression and function of prostaglandin F2a-synthase (PGFS, AKR1C3) and 15-hydroxyprostaglandin dehydrogenase (HPGD). Biol Reprod. 2013;89:2.

44. Jeusette IC, Detilleux J, Shibata H, Saito M, Honjoh T, Delobel A, et al. Effects of chronic obesity and weight loss on plasma ghrelin and leptin concentrations in dogs. Res Vet Sci. 2005;79:169-75. 
45. Nishii N, Takasu M, Ohba Y, Maeda S, Kitoh K, Ohtsuka Y, et al. Effects of administration of glucocorticoids and feeding status on plasma leptin concentrations in dogs. Am J Vet Res. 2006;67:266-70.

46. Ishioka K, Hosoya K, Kitagawa H, Shibata H, Honjoh T, Kimura K, et al. Plasma leptin concentration in dogs: effects of body condition score, age, gender and breeds. Res Vet Sci. 2007;82(1):11-5.

47. Saleri R, Tirelli M, Grasselli F, Dondi M, Arisi M. Sexual dimorphism in leptin blood levels in the dog. Veterinaria. 2003;17:47-51.

48. Balogh O, Kowalewski MP, Reichler IM. Leptin and leptin receptor gene expression in the canine corpus luteum during diestrus, pregnancy and after aglepristone-induced luteolysis. Reprod Domest Anim. 2012;47 Suppl 6:40-2.

49. Sorace M, Tripodi L, Tripodi A, Groppetti D, Cremonesi F. Leptin: pharmacological aspects in gynecology. Clin Exp Obstet Gynecol. 2006;33:113-6.

50. Bartel C, Tichy A, Walter I. Characterization of foamy epithelial surface cells in the canine endometrium. Anat Histol Embryol. 2014;43:165-81.

51. Kowalewski MP, Beceriklisoy HB, Aslan S, Agaoglu AR, Hoffmann B. Time related changes in luteal prostaglandin synthesis and steroidogenic capacity during pregnancy, normal and antiprogestin induced luteolysis in the bitch. Anim Reprod Sci. 2009;116:129-38.

52. Bouchard GF, Solorzano N, Concannon PW, Youngquist RS, Bierschwal CJ. Determination of ovulation time in bitches based on teasing, vaginal cytology, and elisa for progesterone. Theriogenology. 1991;35:603-11.

53. Link KRJ, Allio I, Rand JS, Eppler E. The effect of experimentally induced chronic hyperglycaemia on serum and pancreatic insulin, pancreatic islet IGF-I and plasma and urinary ketones in the domestic cat (Felis felis). Gen Comp Endocrinol. 2013;188:269-81.

54. Kowalewski MP, Schuler G, Taubert A, Engel E, Hoffmann B. Expression of cyclooxygenase 1 and 2 in the canine corpus luteum during diestrus. Theriogenology. 2006;66:1423-30.

55. Kowalewski MP, Mason Jl, Howie AF, Morley SD, Schuler G, Hoffmann B. Characterization of the canine $3 \beta$-hydroxysteroid dehydrogenase and its expression in the corpus luteum during diestrus. J Steroid Biochem Mol Biol. 2006;101:254-62.

56. Kowalewski MP, Meyer A, Hoffmann B, Aslan S, Boos A. Expression and functional implications of peroxisome proliferator-activated receptor gamma (PPARY) in canine reproductive tissues during normal pregnancy and parturition and at antiprogestin induced abortion. Theriogenology. 2011:75:877-86

57. Kitawaki J, Koshiba H, Ishihara H, Kusuki I, Tsukamoto K, Honjo H. Expression of leptin receptor in human endometrium and fluctuation during the menstrual cycle. J Clin Endocrinol Metab. 2000;85:1946-50.

58. Bukowska D, Kempisty B, Jackowska M, Woźna M, Antosik P, Piotrowska H, et al. Analysis of integrins and vascular endothelial growth factor isoforms mRNA expression in the canine uterus during perimplantation period. Pol J Vet Sci. 2011;14:253-8.

59. Reese J, Das SK, Paria BC, Lim H, Song H, Matsumoto H, et al. Global gene expression analysis to identify molecular markers of uterine receptivity and embryo implantation. J Biol Chem. 2001;276:44137-45.

60. Yoon SJ, Cha KY, Lee KA. Leptin receptors are down-regulated in uterine implantation sites compared to interimplantation sites. Mol Cell Endocrinol. 2005;232:27-35

61. Dos Santos E, Serazin V, Morvan C, Torre A, Wainer R, de Mazancourt P, et al. Adiponectin and leptin systems in human endometrium during window of implantation. Fertil Steril. 2012:97:771-8. e1.

62. Ashworth CJ, Hoggard N, Thomas L, Mercer JG, Wallace JM, Lea RG. Placental leptin. Rev Reprod. 2000:5:18-24.

63. Challier J, Galtier M, Bintein T, Cortez A, Lepercq J, Hauguel-de Mouzon S. Placental leptin receptor isoforms in normal and pathological pregnancies. Placenta. 2003;24:92-9.

64. Toth B, Fischl A, Scholz C, Kuhn C, Friese K, Karamouti M, et al. Insulin and leptin receptors as possible new candidates for endocrine control in normal and disturbed human pregnancy. Mol Hum Reprod. 2009;15:231-9.

65. Smolinska N, Siawrys G, Kaminski T, Przala J. Leptin gene and protein expression in the trophoblast and uterine tissues during early pregnancy and the oestrous cycle of pigs. J Physiol Pharmacol. 2007:58:563-81.

66. Smolinska N, Kaminski T, Siawrys G, Przala J. Long form of leptin receptor gene and protein expression in the porcine trophoblast and uterine tissues during early pregnancy and the oestrous cycle. Anim Reprod Sci. 2009:113:125-36.
67. Dall'Aglio C, Polisca A, Boiti C, Ceccarelli P. Immunolocalization of leptin and its receptor in the placenta of cats. Acta Histochem. 2012;114:719-22.

68. Magariños MP, Sánchez-Margalet V, Kotler M, Calvo JC, Varone CL. Leptin promotes cell proliferation and survival of trophoblastic cells. Biol Reprod. 2007;76:203-10.

69. Pérez-Pérez A, Maymó J, Gambino Y, Dueñas JL, Goberna R, Varone C, et al. Leptin stimulates protein synthesis-activating translation machinery in human trophoblastic cells. Biol Reprod. 2009;81:826-32.

70. Madej T, Boguski MS, Bryant SH. Threading analysis suggests that the obese gene product may be a helical cytokine. FEBS Lett. 1995;373:13-8.

71. Molvarec A, Szarka A, Walentin S, Bekő G, Karádi I, Prohászka Z, et al. Serum leptin levels in relation to circulating cytokines, chemokines, adhesion molecules and angiogenic factors in normal pregnancy and preeclampsia. Reprod Biol Endocrinol. 2011;9:124.

72. Nuamah MA, Yura S, Sagawa N, Itoh H, Mise H, Korita D, et al. Significant increase in maternal plasma leptin concentration in induced delivery: a possible contribution of pro-inflammaotry cytokines to placental leptin secretion. Endocr J. 2004;51:177-87.

73. Lappas M, Permezel M, Rice GE. Leptin and adiponectin stimulate the release of proinflammatory cytokines and prostaglandins from human placenta and maternal adipose tissue via nuclear factor-kappaB, peroxisomal proliferator-activated receptor-gamma and extracellularly regulated kinase 1/2. Endocrinology. 2005;146:3334-42.

74. Frühbeck $\mathrm{G}$. Intracellular signalling pathways activated by leptin. Biochem J. 2006;393:7-20.

75. Schulz LC, Widmaier EP. Leptin receptors. In: Castracane VD, Henson MC, editors. Leptin. New York: Springer Science + Business Media LLC; 2006. p. 11-31.

\section{Submit your next manuscript to BioMed Central and take full advantage of:}

- Convenient online submission

- Thorough peer review

- No space constraints or color figure charges

- Immediate publication on acceptance

- Inclusion in PubMed, CAS, Scopus and Google Scholar

- Research which is freely available for redistribution 